\title{
Memahami dan Menerapkan Prinsip Kepemimpinan Orang Muda Menurut 1 Timotius 4:12 bagi Mahasiswa Teologi
}

\author{
Desti Samarenna ${ }^{1 *}$, Harls Evan R. Siahaan² \\ ${ }^{1}$ Sekolah Tinggi Teologi Harvest International, Semarang, Jawa Tengah \\ ${ }^{2}$ Sekolah Tinggi Teologi Pelita Bangsa, Jakarta \\ *destisamarenna@gmail.com
}

\begin{abstract}
Leadership is mostly required in church management. There are many leadership characteristics in the Bible that can be used as leadership patterns in the church. This article is a literature study with a qualitative approach to the text of 1 Timothy 4:12 concerning the leadership of a young person, which aims to encourage students to understand and apply the pattern of leadership referred to in the text of 1 Timothy 4:12. The method used is descriptive analysis in the text of 1 Timothy 4:12, to provide a clear picture and understanding of the principles of leadership of young people. In addition, descriptive methods are also used to determine students' understanding of the principles of leadership according to the text, as well as the level of application in life and service. In conclusion, students understand the principle of leadership in 1 Timothy 4:12, which is about giving an example, but not all students are ready and able to do it.
\end{abstract}

Keywords: young people's leadership; Christian leaders; church leader; example; Timothy

\begin{abstract}
Abstrak: Kepemimpinan merupakan hal yang sangat dibutuhkan dalam manajemen gereja. Ada banyak karakteristik kepemimpinan dalam Alkitab yang dapat dijadikan pola kepemimpinan dalam gereja. Artikel ini merupakan kajian literatur dengan pendekatan kualitatif terhadap teks 1 Timotius 4:12 tentang kepemimpinan seorang muda, yang bertujuan untuk mendorong mahasiswa memahami dan menerapkan pola kepemimpianan yang disebut dalam teks 1 Timotius 4:12 tersebut. Metode yang digunakan adalah deskriptif analasis pada teks 1 Timotius $4: 12$, untuk memberikan gambaran dan pemahaman yang jelas tentang prinsip kepemimpinan orang muda. Selain itu, metode deskriptif juga digunakan untuk mengetahui pemahaman mahasiswa tentang prinsip kepemimpinan menurut teks tersebut, serta tingkat penerapannya dalam kehidupan dan pelayanannya. Kesimpulannya, mahasiswa memahami prinsip kepemimpinan dalam 1 Timotius $4: 12$, yaitu tentang memberikan teladan, namun tidak semua mahasiswa siap dan mampu melakukannya.
\end{abstract}

Kata kunci: kepemimpinan orang muda; pemimpin Kristen; pemimpin gereja; teladan; Timotius

$\begin{array}{llll}\text { Article History : } & \text { Received: 14-12-2018 } & \text { Revised: 18-12-2018 Accepted: 03-05-2019 }\end{array}$




\section{Pendahuluan}

Berbicara tentang kepemimpinan merupakan hal yang tidak pernah usang dalam konteks kepemimpinan Kristen atau gereja. Sekalipun banyak tersedia referensi, baik berupa buku dan modul pelatihan tentang kepemimpanan, namun demikian tema ini masih terus aktual untuk dibahas. Tidak sedikit seminar dengan topik tentang kepemimpinan gereja atau Kristen dilakukan, baik dalam lingkup gereja maupun akademis. Hal ini menunjukkan bahwa kepemimpinan menuntut sebuah dinamika yang dapat menjawab kebutuhan zaman yang terus berubah.

Tema kepemimpinan dalam gereja merupakan hal yang sentral, karena banyak gereja dipisahkan oleh karena perbedaan kepemimpinan. Perbedaan kepemimpinan menghasilkan perbedaan kebijakan, sehingga hal yang lumrah jika ada perbedaan akan berimplikasi pada perpecahan gereja, karena kebijakan merupakan persoalan sensitif dalam hal organisasi, termasuk gereja. ${ }^{1}$ Ini berarti kepemimpinan rawan terhadap konflik dan kepentingan, tidak terkecuali kepemimpinan Kristen. Namun demikian, seorang pemimpin juga harus dapat menjalankan fungsi sebagai seorang yang mampu mengatasi konflik, bukan malah menimbulkan konflik. ${ }^{2}$ Itu sebabnya kepemimpinan senantiasa dikaitkan dengan karakter, karena diharapkan karakter seorang pemimpin mampu memberikan jawaban, solusi dan perubahan positif bagi kehidupan di sekelilingnya. ${ }^{3}$

Pada umumnya, seorang pemimpin seringkali dikaitkan dengan status senioritas; artinya, seorang pemimpin adalah seorang yang lebih tua dalam hal usia. Hal ini disebabkan oleh anggapan bahwa seorang pemimpin sewajarnya adalah seorang yang lebih tua dari orang yang dipimpinnya. Atau, kepemimpinan dikaitkan dengan persoalan gender; meskipun pada masa sekarang ini kepemimpinan perempuan sudah memberikan kontribusi yang signifikan dalam kehidupan organisasi gereja. ${ }^{4}$ Stigma tentang kepemimpinan dengan asas senior dan gender sudah sepantasnya ditinggalkan, karena persoalan kepemimpinan pada masa sekarang ini lebih ditekankan pada persoalan kompetensi pribadi seorang pemimpin.

Pemimpin muda telah banyak muncul di berbagai sektor kehidupan, seperti politik, sosial, hukum, pendidikan, hingga agama. Sebuah portal berita online menuliskan tentang keberadaan pemimpin muda di panggung dunia, seperti: Viktor Orban yang menjadi perdana menteri pada usia 35 tahun; Charles Michel menjadi perdana menteri

\footnotetext{
${ }^{1}$ Sonny Eli Zaluchu, "Analisis Kisah Para Rasul 15 Tentang Konflik Paulus Dan Barnabas Serta Kaitannya Dengan Perpecahan Gereja," KURIOS (Jurnal Teologi dan Pendidikan Agama Kristen) 4, no. 2 (2018): 107-117, www.sttpb.ac.id/e-journal/index.php/kurios.

2Maidiantius Tanyid, "Kualitas Pemimpin Sebagai Pendidik Dalam Menghadapi Konflik," BIA: Jurnal Teologi dan Pendidikan Kristen Kontekstual 1, no. 1 (2018): 124-137, http://www.jurnalbia.com/index.php/bia.

${ }^{3}$ Fernando Tambunan, "Karakter Kepemimpinan Kristen Sebagai Jawaban Terhadap Krisis Kepemimpinan Masa Kini," Illuminate: Jurnal Teologi dan Pendidikan Kristiani 1, no. 1 (2018): 81-104, http://sttbaptis-medan.ac.id/e-journal/index.php/illuminate/article/view/6.

${ }^{4}$ Nunuk Rinukti Siahaya, "Peranan Perempuan Menurut Perjanjian Baru Bagi Perkembangan Kepemimpinan Perempuan Di Dalam Gereja," JURNAL TERUNA BHAKTI 1, no. 1 (2018): 33-41, http://ejournal.stakterunabhakti.ac.id/index.php/teruna/article/view/9.
} 
Belgia pada usia 38 tahun; Juri Ratas menjadi perdana menteri Estonia pada usia 38 tahun; Volodymyr Groysman menjadi perdana menteri Ukkraina pada usia 38 tahun; Alexis Tsipras menjadi perdana menteri Yunani pada usia 40 tahun. ${ }^{5}$ Daftar tersebut masih dapat bertambah. Namun setidaknya beberapa orang telah menunjukkan kiprahnya untuk menjadi pemimpin muda di dunia politik dan pemerintahan.

Dalam konteks kekristenan dan gereja, kepemimpinan yang dipegang oleh orang muda telah menjadi hal yang umum terjadi. Walaupun tidak semua gereja memberlakukan kebijakan seperti demikian, namun beberapa pemimpin gereja yang masih muda dapat ditemukan di beberapa organisas dan denominasi gereja. Memunculkan atau membangkitkan pemimpin muda dalam gereja bukanlah hal yang tabu, melainkan dapat memberikan ruang inovasi dalam hal kepemimpinan. Sebuah penelitian yang dipublikasikan dalam jurnal di Universitas Gadjah Mada, mengungkapkan ada keterkaitan yang erat antara anak muda dan pesoalan inovasi6, bahkan hal tersebut yang membuat karir anak-anak muda sekarang banyak yang melejit. ${ }^{7}$ Orang muda memiliki potensi dalam berinovasi.

Pelayanan oleh orang muda juga menjadi perhatian gereja dalam zaman sekarang ini. Banyak sektor pelayanan gerejawi yang memberdayakan tenaga dari orang-orang muda. Pelayanan orang muda juga tidak lepas dari pemberdayaan karunia yang menjawab kebutuhan dari tantangan zaman. Kepemimpinan pun tidak lepas dari karunia seseorang dalam melayani; karena kepemimpinan dalam konteks pelayanan merupakan ekspresi dan refleksi dari karunia seseorang. Penelitian sebelumnya tentang pemberdayaan diri melalui karunia telah dilakukan oleh Harls Evan R. Siahaan, yang menitikberatkan pada persoalan aktualisasi diri melalui pelayanan karunia. Ada keterbatasan dalam pembahasan yang dilakukan oleh Siahaan, di mana pelayanan karunia dalam hal kepemimpinan tidak mendapatkan porsi pembahasan.

Kepemimpinan orang-orang muda dapat dimulai dari hal sederhana atau kecil dalam gereja, seperti pemimpin guru Sekolah Minggu, Pemuda dan Remaja, kelompok sel muda, dan banyak hal lain yang dapat dipercayakan kepada mereka. Namun demikian, persoalan yang umum terjadi terkait orang-orang muda juga harus dipertimbangkan sebelum memberikan ruang yang lebih luas untuk mereka menjadi pemimpin dalam gereja. Artinya, ada celah negatif yang perlu diantisipasi oleh gereja, agar kepemimpinan orang muda dapat menjadi manfaat bagi keberlangsungan gereja.

Kepemimpinaan orang muda dalam gereja telah dialami sejak dulu kala, pada masa gereja mula-mula hadir di muka bumi. Seorang yang bernama Timotius diberikan

\footnotetext{
5“https://www.liputan6.com/global/read/2944835/selain-Emmanuel-Macron-Ini-PemimpinDunia-Berusia-Muda."

${ }^{6}$ Lak Lak Nahat El Hasanah, "Pengembangan Wirausaha Muda Ekonomi Kreatif Berbasis Budaya Di Daerah Istimewa Yogyakarta," Jurnal Studi Pemuda 4, no. 2 (2018): 268.

${ }^{7}$ Hempri Suyatna and Yanti Nurhasanah, "Sociopreneurship Sebagai Tren Karir Anak Muda," Jurnal Studi Pemuda 6, no. 1 (2018): 527.

${ }^{8}$ Harls Evan R. Siahaan, "Aktualisasi Pelayanan Karunia Di Era Digital," EPIGRAPHE: Jurnal Teologi dan Pelayanan Kristiani 1, no. 1 (2017): 23-38, www.stttorsina.ac.id/jurnal/index.php/epigraphe.
} 
tangung jawab dan kepercayaan untuk memimpin sebuah gereja di Efesus oleh Paulus. Timotius yang masih muda dan miskin pengalaman pelayanan harus mengemban tugas kepemimpinan tersebut. Setidaknya inilah suasana yang memunculkan nasihat kepemimpinan Paulus dalam suratnya 1 Timotius 4:12, kepada Timotius yang merupakan anak didiknya.

Kepemimpinan Timotius bukanlah hal baru dalam kepemimpinan Kristen. Beberapa buku kepemimpinan Kristen menyinggung tentang topik dalam 1 Timotius 4:12. Beberapa kajian pun telah dilakukan berkaitan dengan kepemimpinan berdasarkan surat 1 Timotius, seperti yang dilakukan oleh Christine Fuceria Ginting', namun pembahasan tidak terfokus pada 1 Timotius 4:12 dengan topik kepemimpinan orang muda, melainkan meluas pada kepemimpinan penggembalaan di surat itu. Topik tentang 1 Timotius 4:12 belum banyak tersedia dalam bentuk kajian yang dijurnalkan, kecuali dalam bentuk renungan-renungan singkat atau serial khotbah tentang pribadi Timotius dan tugas pelayanannya yang diberi mandat oleh Paulus.

Ada beberapa buku serial iman Kristen atau renungan singkat yang membahas pokok 1 Timotius 4:12 dengan memberikan pemahaman sederhana tentang nasihat Paulus kepada Timotius sebagai anak didiknya di dalam Tuhan untuk memimpin sebuah jemaat di Efesus. Tema-tema khotbah tersebut merupakan pengajaran ideal dan normatif tentang bagaimana seharusnya seorang muda menjadi pemimpin dalam konteks penggembalaan. Wilayah normatif itu sebaiknya tidak mengabaikan fenomena dalam masyarakat gereja tentang kepemimpinan yang terjadi. Penelitian ini melihat sebuah fakta dari fenomena kepemimpinan seorang muda dalam konteks pelayanan di gereja.

Penelitian ini bertujuan untuk menunjukkan fakta dari fenomena mahasiswa teologi, sebagai orang-orang muda yang mencoba memahami dan menerapkan teks tersebut dalam kerangka pelayanan gerejawi. Pembahasan dan kajian sebelumnya, lebih banyak bertendensi pada persoalan normatif, yakni menyampaikan pesan teologis pada ranah tafsir bagaimana seharusnya seorang muda menjadi pemimpin sesuai dengan teks 1 Timotius 4:12. Itu sebabnya, pembahasan ini memiliki kepentingan untuk mempertimbangkan berbagai fenomena aktual yang berkaitan dengan kehidupan orang-orang muda di masanya.

\section{Metode Penelitian}

Penelitian ini merupakan kajian literatur teks Alkitab dalam 1 Timotius 4:12 yang memuat tentang prinsip kepemimpinan orang muda dalam konteks kepemimpinan Kristen. Pendekatan yang digunakan adalah kualitatif, dengan menerapkan metode deskriptif analisis pada teks 1 Timotius 4:12, sehingga didapati beberapa prinsip tentang kepemimpinan. Penelitian ini juga menggunakan instrumen angket untuk memperoleh data tentang pemahaman dan progresivitas dalam menerapkan teks

\footnotetext{
${ }^{9}$ Christine Fuceria Ginting, "Konsep Kepemimpinan Penggembalaan Berdasarkan 1 Timotius Dan Aplikasinya Terhadap Pertumbuhan Rohani Jemaat," Jurnal Teologi Pantekosta 1, no. 1 (2018): 78-89, http://sttpantekostasumutaceh.ac.id/e-journal/index.php/pneustos.
} 
tersebut di kalangan orang-orang muda. Populasi penelitian merupakan seluruh mahasiswa Sekolah Tinggi Teologi Torsina Surakarta tahun ajaran 2018/2019, pada jenjang tingkat I-III yang berjumlah 41 orang. Seluruh populasi menjadi responden dalam penelitian ini.

Teks 1 Timotius 4:12 dipahami secara deskriptif dengan beberapa langkah, yakni mendeskripsikan latar belakang surat, kepenulisan, karakteristik Timotius sebagai penerima, serta analisis gramatikal teks tersebut untuk merumuskan beberapa poin berkaitan dengan prinsip kepemimpinan orang muda.

\section{Survei Surat 1 Timotius}

Surat yang memakai namanya ini dimaksudkan untuk membesarkan hati dan meneguhkan dia untuk menerima tugas berat yang dilimpahkan Paulus kepadanya. ${ }^{10}$ Ia bertobat pada usia kurang lebih lima belas tahun, ketika Rasul Paulus mengunjungi kota asalnya, Listra (Kis 16:1-3; 1Tim 1:2). Tujuh tahun kemudian ia ikut dalam pelayanan penginjilan Paulus dan terjalinlah hubungan persahabatan yang sangat erat antara Paulus yang saat itu sudah berumur kira-kira tujuh puluh tahun dengan rekannya yang lebih muda. Pertemuan pertama Paulus dengan Timotius diberitakan dalam Kisah Para Rasul 16:2-3.

Tahun 53 sampai 56 Timotius tinggal bersama dengan Paulus di Efesus; dari sana ia diutus ke Makedonia (Kis.19:22), lalu ia ke Korintus (1 Kor. 4:17; 6:10). Tmotius juga pernah bersama Paulus di Makedonia (2 Kor. 1:1). Lalu, di Korintus kembali (Rm. 16:21). Paulus menulis surat kepadanya dari Korintus untuk memberikan dorongan kepadanya dan beberapa nasihat. Ayat kunci surat ini terdapat dalam 1 Timotius 3:15. Paulus sangat ingin melihat anak rohaninya memenuhi tanggung jawabnya sebagai seorang pemimpin. Ia berkeinginan supaya dalam segala hal Timotius dapat memberi teladan kepada jemaat yang mengharapkan kepemimpinannya (1 Tim. 4:12).

Teks 1 Timotius 4:12 berada pada konteks pasal satu yang secara garis besar berisikan: sikap Paulus yang menghormati Timotius secara khusus (1:1-14), salam dan terima kasih (1-5), nasihat yang menguatkan hati dan menasihatinya (1-13), nasihat mengenai tindakan menghadapi pengajar-pengajar sesat (1:14-16); nasihat bagi Timotius supaya tetap setia seperti pada mulanya (1:13-17). ${ }^{11}$ Timotius merupakan sosok yang penuh kasih sayang (2 Tim. 1:4), tetapi juga sangat penakut (2 Tim. 1:7), sehingga ia memerlukan banyak nasihat pribadi agar tidak tergoda oleh nafsu orang muda (2Tim. 2:22), dan supaya jangan malu menyaksikan Injil (2Tim. 1:8). ${ }^{12}$

\section{Analisis Teks}

Teks 1 Timotius 4:12 (LAI) adalah sebagai berikut: “Jangan seorang pun menganggap engkau rendah karena engkau muda. Jadilah teladan bagi orang-orang

\footnotetext{
10Merrill C. Tenney, Survey Perjanjian Baru (Malang: Gandum Mas, 2001), 415.

11Donald Guthrie, "Timotius," in Ensiklopedi Masa Kini,Jil., II M-Z (Jakarta: Yayasan Komunikasi Bina Kasih/OMF, 1999), 479-480.

12Ibid.
} 
percaya, dalam perkataanmu, dalam tingkah lakumu, dalam kasihmu, dalam kesetiaanmu dan dalam kesucianmu." Dengan teks dalam bahasa Yunani:

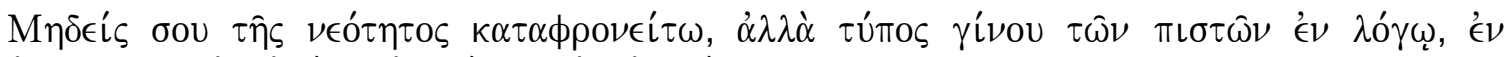

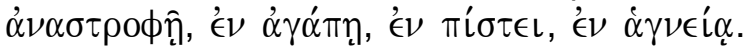

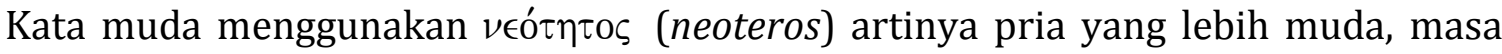
muda. ${ }^{13}$ Muda menjelaskan tentang tingkatan usia. Dalam kebudayaan Perjanjian Baru, usia lanjut merupakan sesuatu yang dihormati dan kemudaan dinilai rendah. ${ }^{14}$ Kata katafrone,w (katafroneo) artinya memandang remeh. Katafroneo dalam bentuk datif artinya menghina, mencemooh, meremehkan. ${ }^{15}$ Paulus memulai ayat kedua belas dengan frasa "jangan seorang pun menghina masa mudamu."Umur jangan sampai menjadi kendala bagi Timotius untuk menjadi seorang pemimpin yang memiliki integritas. Paulus mendorong Timotius sebagai pemimpin muda agar berani memenuhi tanggung jawabnya.

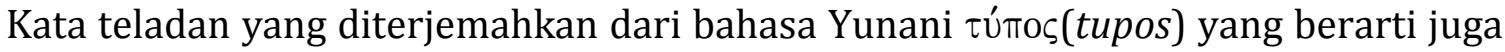
contoh, teladan, model. Maknanya memiliki nuansa the mark (of a blow), an impression, stamp (made by a die) dalam pemakaian bahasa Inggris diterjemahkan example digunakan sebanyak 3 kali, dan kata pattern digunakan sebanyak 3 kali juga dan digunakan dalam Matius 1:19; Ibrani 4:11; 8:5; 1 Petrus 2:21 Yudas 7.16 Kata tupos dihubungkan dengan kehidupan moral seperti yang dijelaskan dalam Matius 1:19; Filipi 3:17; 1 Tesalonika 1:7; 2 Tesalonika 3:9; 1 Timotius 4:12; Titus 2:7; 1 Petrus 5:3, 1 Kolose 16:11; Titus 2:15,1Timotius 1:14. Artinya, kata tupos berkaitan langsung dengan integritas kehidupan moral seseorang; itu sebabnya Paulus sangat menekankan keteladanan dalam kepemimpinan orang muda. Teladan bagi orang percaya berarti otoritas pemimpin muda ditentukan oleh integritas atau kepercayaan. ${ }^{17}$ Sementara, kesombongan dan kebodohan seringkali membuat pemimpin muda dicela. ${ }^{18}$

Terkait dengan nasihat Paulus tentang keteladanan (tupos), beberapa hal yang ditekankan kepada Timotius adalah:

\section{Teladan dalam Perkataan}

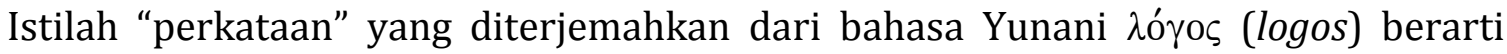
sebuah kata, sebuah pernyataan, sebuah pidato, atau bias juga firman. ${ }^{19}$ Secara harafiah perkataan adalah kata dan menunjuk kepada percakapan pada umumnya. Dalam hidup

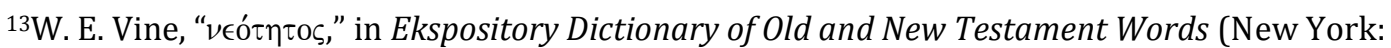
Fleming H. Revell Company, 1981). 247.

${ }^{14}$ Daniel C. Arichea and Howard A. Hattan, Pedoman Penafsiran Alkitab Surat-Surat Paulus Kepada Timotius Dan Titus (Jakarta: Lembaga Alkitab Indonesia, 2014), 96.

${ }^{15}$ B.F Drewes, Wilfrid Haubeck, and Heinrich von Siebenthal, "K $\alpha \tau \alpha \phi \rho o \nu ' \omega$, ," in Bahasa Yunani Perjanjian Baru: Surat Roma Hingga Wahyu (Jakarta: BPK Gunung Mulia, 2010), 219.

16James Strong, "Example," in The New Strong's Concordance of The Bible (New York: Thomas Nelson Publisher, 1985), 205.

${ }^{17}$ Larry Stout, Model Kepemimpinan Ideal Yang Mengubah Dunia (Yogyakarta: ANDI Offset, 2010), 45.

${ }^{18}$ Matthew Henry, "1 Timothy," in Commentary On The Whole Bible:Genesis to Revelation (Michigan: Regency Reference Library, 1960), 1890.

${ }^{19}$ Henk ten Napel, Kamus Teologi Inggris-Indonesia (Jakarta: BPK Gunung Mulia, 1999), 332.
} 
sehari-hari, perkataan menentukan situasi yang dihadapi. Perkataan seseorang akan sangat mempengaruhi kualitas dirinya. Oleh karena itu, sebuah kata menentukan keadaan atau situasi yang dihadapi. Amsal 18:21 menegaskan tentang hidup dan mati sesseorang yang dikuasai oleh lidah, karena siapa yang menggemakannya akan merasakan dampaknya. Hal ini menegaskan bahwa kata-kata atau perkataan seseorang menentukan kehidupannya. Setiap perkataan yang diungkapkan harus dapat dipertanggunjawabkan.

Pemahaman ini sangat sederhana dan dapat dimengerti secara jelas, tentang bagaimana seseorang harus dapat menjadi teladan dalam perkataan. Dalam bingkai kepemimpinan, baik secara umum maupun dalam konteks kekristenan, perkataan atau ucapan seorang pemimpin merupakan hal yang menunjukkan integritasnya. Pemimpin dapat berbicara hal-hal yang bombastis, menebar janji-janji, teori-teori, yang kesemuanya itu akan dibuktikan lewat buah dari perkataannya.

Selain itu pemahaman teladan dalam perkataan dapat berarti juga seseorang tidak mudah berkata-kata yang menjatuhkan, menghujat, menghina, mendiskreditkan, mencaci, hate speech, bohong, tipu muslihat, dan hal-hal negatif dalam perkataan lainnya. Seorang pemimpin adalah seorang yang membangun, baik dalam kelompok yang kawan maupun lawan. Dalam hal seperti itulah seorang muda yang ingin memimpin harus menunjukkan kualitas dirinya, yakni dengan memberikan teladan dalam perkataan.

\section{Teladan dalam Tingkah Laku}

Teladan yang kedua adalah dalam hal tingkah laku. Istilah Yunani yang diguanakan untuk tingkah laku adalah avnastrofh ,(anastrophe), yang berarti perilaku, gaya hidup, hidup, percakapan. ${ }^{20}$ Istilah ini menunjuk pada sikap hidup sehari-hari. Tingkah laku sehari-hari akan menghasilkan sebuah kebiasaan yang melibatkan kepribadian yang tercermin melalui perkataan, penampilan, tindakan, cara berpakaian dan cara menghadapai setiap persoalan. Dalam makna ini seluruh sikap dan perbuatan seseorang merupakan suatu gambaran dari kepribadian orang itu, asal dilakukan secara sadar. Kepribadian dapat menentukan apakah seseorang menjadi pemimpin yang baik atau akan menjadi perusak atau penghancur bagi hari depan sebuah organisasi, bangsa atau gereja. Oleh karena itu, kepribadian adalah suatu hal yang sangat menentukan tinggi rendahnya kewibawaan seorang pemimpin muda.

\section{Teladan dalam Kasih}

Kasih adalah sebuah tindakan yang dilakukan berdasarkan kasih kasih Allah. Sebuah pilihan yang dapat dikendalikan dan sesuatu yang dapat dilakukan bukan berdasarkan kasih atau perasaan kepada saudara seiman atau lawan jenis. Rasul Yohanes mengungkapkannya, "marilah kita mengasihi bukan dengan perkataan atau dengan lidah tetapi dengan perbuatan dalam kebenaran." Kasih merupakan satu kata

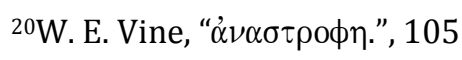


inti dari ajaran yang pertama dan terutama yang Kristus ajarkan kepada gereja. Kasih juga menjadi dasar dari seluruh hukum yang ada, terutama Taurat.

Pengertian kata kasih dalam 1 Timotius 4:12 adalah agape yang secara sederhana dapat berarti kasih yang Ilahi. Roger Roberts menggambarkan kasih ibarat rantingranting yang menyatukan anggur-anggur menjadi setandan buah anggur itu; dia bukan unsur terpisah dari yang lain, melainkan intisari dari unsur-unsur lainnya. Paulus dalam surat 1 Korintus 13: 4 menguraikan prinsip kasih, dan konsep ini pun yang dapat dipahami oleh Timotius tentang kasih yang seharusnya diteladankan dalam kepemimpinannya.

Intinya, kepemimpinan bukan semata-mata tentang jalur komando atau berupa seperangkat perintah untuk melakukan ini dan itu, melainkan juga bagaimana seorang pemimpin memberikan teladan tentang kasih dalam kehidupannya. Ia haruslah seorang yang terlebih dahulu mengasihi dan melakukannya secara tulus hingga menjadi sebuah budaya dalam kehidupannya. Dalam hal inilah kepemimpinan yang diinginkan Paulus kepada Timotius untuk diterapkan dalam pelayanannya di Efesus.

\section{Teladan dalam Kesetiaan}

Kesetiaan merupakan paduan dari kepercayaan serta keyakinan terhadap Yesus Kristus, dan juga kesetiaan kepadaNya. Kualitas keteladanan seorang pemimpin yang keempat adalah kesetiaan. Dalam terjemahan bahasa Yunani dipakai kata mí $\tau \iota \varsigma$ (pistis) yang juga berarti iman, kesetiaan (1 Kor. 16:11; Gal. 1:23; 1 Tim. 1:14, Tit. 2:7, 15; 1 Pet. 5:3). Dua hal ini merupakan satu kesatuan, antara iman dan kesetiaan. Iman yang membuat seseorang setia, tetap bertahan dalam sebuah keadaan karena percaya pada apa yang telah dijanjikan atau didengarkan.

Kesetiaan merupakan unsur yang penting dalam kepemimpinan Kristen. Kesetiaan berbicara tentang keutuhan seorang pemimpin. Patron yang paling utama tentu Yesus, sebagai acuan kepemimpinan Kristen. Kesetiaan Yesus tidak perlu diragukan, dan teruji hingga Ia mati. Kesetiaan berbicara tentang bagaimana sebuah pekerjaan atau misi dikerjakan hingga selesai. Pada bagian ini jugalah seorang Timotius diminta oleh Paulus untuk dapat menjadi teladan.

\section{Teladan dalam Kesucian}

Kesucian merupakan istilah umum bagi kehidupan yang benar dan tidak bercela. Kesucian dalam bahasa Yunani $\dot{\alpha} \gamma \nu \in i \alpha$ (hagneia) yang dapat berarti kemurnian. Kata ini juga digunakan ti tempat lain oleh Paulus, seperti: 1 Korintus 16:11 dan Titus 2:7, 15. Paulus menaikkan satu tingkat keteladanan yang lebih dari pemimpin yang lain adalah kesucian, karena bagi Paulus kesucian adalah mendemonstrasikan kehidupan yang saleh di depan semua orang. ${ }^{21}$ Istilah Yunani tentang kekudusan dari kata dasar ó $\gamma$ íó (hagios), yang diartikan dengan memisahkan dan menjadikan sesuatu atau seseorang milik Allah. Istilah ini juga menyatakan bahwa Allah adalah satu-satunya yang kudus

${ }^{21}$ A. Duane Liftin, "Timothy," in The Bible Knowledge Commentary: An Exposition of the Scriptures, ed. John F. Walvoord and Roy B. Zuck (England: Victor Books, 1984), 741. 
(Hos. 11:9, Yoh. 17:11). Namanya harus dikuduskan dalam arti Allah itu harus diakui sebagai Allah semua manusia (Yes. 6:3; Mat. 6:9). Selain itu istilah hagios ini adalah juga menunjukkan sikap kesetiaan manusia terhadap Allah atau keserasian dunia ciptaan dengan hukum ilahi. ${ }^{22}$

Konsep hagios tidak digunakan untuk relasi manusia dalam hubungan kultus, tapi sejumlah besar peristiwa hagios digunakan pada pribadi dan sangat penting dalam hubungan pribadi dengan Tuhan (Yoh. 17:11, 1 Pet. 1:15). ${ }^{23}$ Hagios mempunyai dasar pemikiran yang sama mengenai keterpisahan dan kesucian terhadap Allah. Prinsipnya, Paulus menginginkan Timotius agar menunjukkan sikap hidup yang suci bukan sematamata pada tataran kultus atau ibadah semata, melainkan kehidupan sehari-hari. Teladan inilah yang Paulus tekankan menjadi salah satu kualifikasi kepemimpinan Timotius.

\section{Deskripsi Pemahaman dan Penerapan Mahasiswa Teologi tentang 1 Timotius 4:12}

Teks 1 Timotius 4:12 bukan termasuk nas yang asing di kalangan gereja, khususnya orang muda. Namun demikian tidak semua dapat mengidentifikasi nas ini secara tepat dan jelas. Tabel di bawah ini menunjukkan bagaimana deskripsi pemahaman 41 orang mahasiswa terhadap teks tersebut. Tingkat pemahaman dan penerapan dibagi dalam 5 kriteria yang diwakili dengan angka, seperti: sangat tinggi (1); tinggi (2); sedang (3); rendah (4); sangat rendah (5).

\section{Tabel 1: Deskripsi Pemahaman dan Penerapan Mahasiswa}

\begin{tabular}{llccccc} 
No Item Deskripsi & 1 & 2 & 3 & 4 & 5 \\
\hline 1 & Mampu menghafal secara tepat nas 1 Timotius 4:12 & 5 & 12 & 11 & 8 & 5 \\
2 & Mengerti latar belakang dan tujuan penulisan surat 1 Timotius & 6 & 14 & 14 & 4 & 3 \\
3 & Memahami makna dan pesan dari nas 1 Timotius 4:12 & 14 & 10 & 6 & 7 & 4 \\
4 & Pernah membagikan 1 Timotius 4:12 dalam khotbah atau renungan & 9 & 8 & 3 & 7 & 14 \\
5 & Menjadi pemimpin, baik di gereja maupun sekolah & 10 & 11 & 2 & 3 & 15 \\
6 & Menerapkan keteladanan dalam perkataan & 4 & 7 & 10 & 16 & 4 \\
7 & Menerapkan keteladanan dalam tingkah laku & 2 & 6 & 21 & 10 & 2 \\
8 & Menerapkan keteladanan dalam kasih & 11 & 13 & 13 & 3 & 0 \\
9 & Menerapkan keteladanan dalam kesetiaan & 3 & 6 & 14 & 12 & 6 \\
10 & Menerapkan keteladanan dalam kesucian & 6 & 9 & 17 & 5 & 4 \\
\hline
\end{tabular}

${ }^{22}$ Xaper Leon Defour, Ensiklopedia Perjanjian Baru (Yogyakarta: Kanisius, n.d.), 511.

${ }^{23}$ Hasan Sutanto, Perjanjian Baru Interlinear Yunani-Indonesia Dan Konkordansi Perjanjian Baru (Jakarta: Percetakan LAI, 2004), 12. 
Tabel di atas merupakan hasil penilaian dari angket yang dibagikan kepada seluruh mahasiswa yang berjumlah 41 orang.

\section{Pembahasan}

Kepemimpinan orang muda merupakan hal yang sedang mengalami dinamika dalam segala aspek kehidupan, termasuk kepemimpinan dalam gereja dan pelayanan gerejawi. Konsep 1 Timotius 4:12 sebagai permodelan kepemimpinan orang muda, atau kualifikasi dalam kepemimpinan Kristen bagi orang-orang muda coba diimplementasikan dalam konteks mahasiswa Sekolah Tinggi Teologi (STT) sebagai calon pemimpin gereja di masa datang. Seluruh mahasiswa merupakan mahasiswa yang tinggal di asrama STT, sehingga dalam mencari dan mengumpulkan informasi, baik secara kuantitatif maupun kualitatif dapat dilakukan secara baik. Hanya saja harus diakui ada beberapa keterbatasan yang mungkin diperoleh dalam hal pengumpulan data melalui angket, karena ada mahasiswa yang mencoba menjawab secara normatif dan kurang obyektif.

Dari 41 orang mahasiswa, jumlah mahasiswa tigkat 1 ada 17 orang, tingkat 2 ada 13 orang dan tingkat 3 ada 11 orang. Jumlah mahasiswa tingkat yang paling banyak pada tahun ajaran 2018/2019, dan mereka berasal dari latar belakang pendidikan yang tidak merata secara pencapaian kognitifnya. Angket yang diberikan diisi secara realistis dan obyektif menurut pemahaman mereka, walau ada beberapa hal yang mungkin cenderung bersifat normatif, seperti pertanyaan yang berkaitan kesucian atau tingkah laku.

Ketika ditanya mengenai kemampuan mengahafal nas 1 Timotius 4:12, maka tidak semua mahasiswa dapat menghafal secara pas atau tepat, selain dari 5 orang mahasiswa saja. 12 orang mampu menghafal dengan sedikit mengulang bagian yang salah, atau diam beberapa saat untuk mengingat; bagian ini diperhitungkan sebagai tingkatan yang tinggi, karena tetap dapat menghafal nas tersebut. 11 orang yang sedang karena tidak menghafal secara tepat hanya bagian intinya saja. Ada 8 orang yang hanya dapat menyebut bagian akhirnya saja, dan 5 oran sama sekali tidak dapat menghafalnya.

Pada pemahaman tentang latar belakang atau survei tentang surat Timotius hampir semua mahasiswa mampu memahami, kecuali 3 orang yang sama sekali tidak dapat menjelaskan secara garis besar. Demikian juga tentang makna nas tersebut, hampir sebagian besar mampu memahaminya. Hal tersebut dikarenakan mata kuliah pengantar Perjanjian Baru telah mereka peroleh sejak tingkat pertama. Dengan memahami latar belakang surat Timotius, maka mahasiswa dapat memahami makna dan pesan yang disampaikan Paulus kepada Timotius pada saat itu; mengapa Paulus menekankan keteladanan dalam kepemimpinan orang muda.

Ada 14 orang yang belum pernah mengkhotbahkan nas 1 Timotius 4:12 dikarenakan kebanyakan mereka masih tingkat 1 , belum mendapatkan jadwal khotbah baik di lingkungan STT maupun di gereja tempat mereka melayani. Atau karena memang tidak menggunakan tema itu dalam khotbah mereka. Ada 7 orang yang menggunakan nas tersebut sebagai acuan sekunder dengan nas utama yang berkaitan dengan tema orang muda atau keteladanan. Demikian pula dalam hal memimpin, baik di lingkungan 
kampus maupun gereja, ada 15 orang yang belum memperoleh pengalaman tersebut. Sekali lagi, faktor yang sangat memungkinkan karena mereka baru di tingkat awal.

Bagian yang tersulit adalah pada 5 item berikutnya, mengenai menjadi atau memberikan teladan. Pada bagian menerapkan keteladanan mahasiswa terlihat cenderung memilih bagian yang "aman", yaitu dengan sedang atau rendah. Hal ini disebabkan beberapa hal, seperti perasaan enggan untuk menunjukan diri mampu memberikan keteladanan. Beberapa juga menghindari level yang paling rendah oleh karena stigma yang kurang rohani. Tapi secara keseluruhan ada ekspresi bahwa persoalan memberikan teladan merupakan hal yang sulit dan tidak semudah berkata atau khotbah.

Hanya 4 orang yang dengn yakin mengisi bagian sangat tinggi dalam hal memberikan keteladanan dalam hal perkataan. Hal tersebut dikarenakan mereka memang mencoba menerapkan prinsip berkata-kata positif atau yang memberkati. Teladan dalam perkataan menyangkut banyak hal, seperti tidak berbohong, menipu, menghina dan perkataan negatif lainnya. Masih ada mahasiswa yang terkadang terpancing oleh keadaan dan mengeluarkan kata-kata yang cenderung negatif, kurang bersyukur, banyak mengeluh, atau gosip.

Hal yang unik adalah dalam keteladanan kasih. Tidak ada yang mengidentifikasikan dirinya dengan tingkat paling rendah, atau, dengan kata lain, tidak ada yang memilih paling rendah dalam hal kasih. Hanya 3 orang yang mengidentifikasi diri pada level rendah, dan yang paling banyak adalah sedang. Level ini dianggap paling aman, tidak terlalu munafik untuk mengisi dua level di atasnya. Namun demikian ada 11 orang yang melihat dirinya sebagai orang yang sangat mengasihi.

Dalam keteladanan kesucian, hanya 4 orang yang menganggap dirinya sangat rendah dan 5 orang menganggap rendah. Kesucian ini bukan pada persoalan moral belaka, melainkan persoalan etis yang lebih luas dan berkaitan dengan kepemimpinan. Semua orang Kristen harus menyakini bahwa sesungguhnya semua orang beriman, tanpa kecuali dipanggil untuk hidup kudus kepada kesempurnaan kasih. Panggilan untuk hidup kudus berlaku bagi semua orang percaya yang didasarkan pada karya pengorbanan Kristus. ${ }^{24}$ Kecenderungan hati pada dunia atau hal-hal duniawi juga berkaitan dengan kesucian yang dikategorikan di sini.

Jiwa muda sarat dengan persoalan nafsu duniawi, oleh sebab itu banyak hal tentang orang muda dikaitkan dengan hal-hal duniawi. Namun demikian, proses penyucian menuju kesempurnaan bukanlah jalan bebas hambatan sehingga semua orang akan otomtis hidup suci oleh karena telah disucikan oleh pengorbanan Yesus. Setiap orang percaya, bahkan pemimpin butuh perjuangan untuk dapat hidup dalam kesucian, sebelum akhirnya ia memberikan contoh kepada jemaat yang dilayani sebagai orangorang yang dipimpin.

${ }^{24}$ F.J. Moloney, Menjadi Murid Dan Nabi, Model Hidup Religius Menurut Kitab Suci (Yogyakarta: Kanisius, 1998), 11-12. 
Pada akhirnya, keteladanan merupakan sebuah cara untuk menunjukkan hidup yang telah dihidupi oleh seorang pemimpin. Nasihat Paulus tentang memberikan teladan sebagai kualifikasi kepemimpinan orang muda, menjadi sebuah refleksi bagi mahasiswa teologi yang dipersiapkan menjadi pemimpin dalam bidang pelayanan yang dipersiapkan baginya. Itu sebabnya, ada banyak hal yang dapat dipelajari dari nas ini, dengan mempertimbangkan beberapa faktor-faktor kesulitan demi menemukan sebuah pola untuk membangun keteladanan hidup para mahasiswa teologi sebagai pemimpin orang muda.

\section{Kesimpulan}

Kepemimpinan orang muda yang dinasihatkan Paulus kepada Timotius dalam 1 Timotius 4:12 merupakan kepemimpinan yang membutuhkan kualifikasi hidup yang mampu memberikan keteladanan. Pemahaman terhadap surat Timotius akan memberikan kemampuan mahasiswa untuk menerapkan hal-hal yang berkaitan dengan kepemimpinan, yakni keteladanan hidup. Keteladanan yang disyaratkan dalam kepemimpinan orang muda menuntut sebuah proses pembiasaan hidup dalam nilainilai tersebut hingga menjadi sebuah budaya yang melekat sebelum pada akhirnya para mahasiswa memberikan contoh kepada jemaat atau gereja secara umum.

\section{Referensi}

A. Duane Liftin. "Timothy." In The Bible Knowledge Commentary: An Exposition of the Scriptures, edited by John F. Walvoord and Roy B. Zuck. England: Victor Books, 1984.

Arichea, Daniel C., and Howard A. Hattan. Pedoman Penafsiran Alkitab Surat-Surat Paulus Kepada Timotius Dan Titus. Jakarta: Lembaga Alkitab Indonesia, 2014.

Donald Guthrie. "Timotius.” In Ensiklopedi Masa Kini,Jil., II M-Z. Jakarta: Yayasan Komunikasi Bina Kasih/OMF, 1999.

Drewes, B.F, Wilfrid Haubeck, and Heinrich von Siebenthal. "Katafrone,w." In Bahasa Yunani Perjanjian Baru: Surat Roma Hingga Wahyu. Jakarta: BPK Gunung Mulia, 2010.

F.J. Moloney. Menjadi Murid Dan Nabi, Model Hidup Religius Menurut Kitab Suci. Yogyakarta: Kanisius, 1998.

Ginting, Christine Fuceria. "Konsep Kepemimpinan Penggembalaan Berdasarkan 1 Timotius Dan Aplikasinya Terhadap Pertumbuhan Rohani Jemaat." Jurnal Teologi Pantekosta 1, no. 1 (2018): 78-89. http://sttpantekostasumutaceh.ac.id/ejournal/index.php/pneustos.

El Hasanah, Lak Lak Nahat. "Pengembangan Wirausaha Muda Ekonomi Kreatif Berbasis Budaya Di Daerah Istimewa Yogyakarta." Jurnal Studi Pemuda 4, no. 2 (2018): 268.

Hasan Sutanto. Perjanjian Baru Interlinear Yunani-Indonesia Dan Konkordansi Perjanjian Baru. Jakarta: Percetakan LAI, 2004.

Henk ten Napel. Kamus Teologi Inggris-Indonesia. Jakarta: BPK Gunung Mulia, 1999.

James Strong. "Example." In The New Strong's Concordance of The Bible. New York: Thomas Nelson Publisher, 1985.

Larry Stout. Model Kepemimpinan Ideal Yang Mengubah Dunia. Yogyakarta: ANDI Offset, 2010. 
Matthew Henry. "1 Timothy." In Commentary On The Whole Bible:Genesis to Revelation. Michigan: Regency Reference Library, 1960.

Merrill C. Tenney. Survey Perjanjian Baru. Malang: Gandum Mas, 2001.

Siahaan, Harls Evan R. "Aktualisasi Pelayanan Karunia Di Era Digital.” EPIGRAPHE: Jurnal Teologi dan Pelayanan Kristiani 1, no. 1 (2017): 23-38. www.stttorsina.ac.id/jurnal/index.php/epigraphe.

Siahaya, Nunuk Rinukti. "Peranan Perempuan Menurut Perjanjian Baru Bagi Perkembangan Kepemimpinan Perempuan Di Dalam Gereja." JURNAL TERUNA BHAKTI 1, no. 1 (2018): 33-41. http://ejournal.stakterunabhakti.ac.id/index.php/teruna/article/view/9.

Suyatna, Hempri, and Yanti Nurhasanah. "Sociopreneurship Sebagai Tren Karir Anak Muda." Jurnal Studi Pemuda 6, no. 1 (2018): 527.

Tambunan, Fernando. "Karakter Kepemimpinan Kristen Sebagai Jawaban Terhadap Krisis Kepemimpinan Masa Kini." Illuminate: Jurnal Teologi dan Pendidikan Kristiani 1, no. 1 (2018): 81-104. http://sttbaptis-medan.ac.id/ejournal/index.php/illuminate/article/view/6.

Tanyid, Maidiantius. "Kualitas Pemimpin Sebagai Pendidik Dalam Menghadapi Konflik." BIA: Jurnal Teologi dan Pendidikan Kristen Kontekstual 1, no. 1 (2018): 124-137. http://www.jurnalbia.com/index.php/bia.

W. E. Vine. "Neo,thtoj." In Ekspository Dictionary of Old and New Testament Words. New York: Fleming H. Revell Company, 1981.

Xaper Leon Defour. Ensiklopedia Perjanjian Baru. Yogyakarta: Kanisius, 1989.

Zaluchu, Sonny Eli. "Analisis Kisah Para Rasul 15 Tentang Konflik Paulus Dan Barnabas Serta Kaitannya Dengan Perpecahan Gereja." KURIOS (Jurnal Teologi dan Pendidikan Agama Kristen) 4, no. 2 (2018): 107-117. www.sttpb.ac.id/ejournal/index.php/kurios.

"https://www.liputan6.com/global/read/2944835/selain-Emmanuel-Macron-IniPemimpin-Dunia-Berusia-Muda." 